\title{
Interleukin 9 Measurement
}

National Cancer Institute

\section{Source}

National Cancer Institute. Interleukin 9 Measurement. NCI Thesaurus. Code C74837.

The determination of the amount of interleukin 9 present in a sample. 